\title{
An Appraisal of Effective Provision of Guidance and Counseling Services in Cameroon State Universities; Trends and Challenges
}

\author{
Tita-Nghamun Johnson Bobga \\ Ph.D. Fellow, Department of Educational Psychology, Faculty of Education, University of Buea, \\ Lecturer, Government Teacher Training College. (GTTC) Limbe, Cameroon. \\ Researcher at "Foundation of Scientific Research, Community Based Rehabilitation and Advocacy \\ on Inclusive Education" (FORCAIE-Cameroon) \\ bobgatit@yahoo.com
}

\begin{abstract}
Effective Guidance and counselling programmes in Cameroon state Universities was aimed at assisting students harmonize their abilities, interests and values and thereby develop their full potential. All this is geared towards improving the self-image of the students and facilitating better achievement in academic performance. This conceptual paper sought to establish the influence of guidance and counselling programme or services on Cameroon state Universities and how such services enhance academic performance of students in Cameroon. Students studying in Institutions of higher learning in Cameroon display a host of problems ranging from poor academic performance to low self esteem, which drive them to open drunkenness, skipping of classes, stealing other people's property, sexual misconduct and actual or attempted suicide. The problems exist despite the fact that guidance and counseling personnel in place in these institutions. The purpose of this study therefore was to establish the challenges facing effective implementation of guidance and counselling programmes in Cameroon state Universities. The paper conceptually explores the meaning and relevance of guidance and counseling services in Universities. An empirical gap was establish based on the fact that, due to continuous allocation of counselors in Universities and secondary schools in Cameroon, students still manifest anti-social behaviours, cheat during exams, indulge into premarital sex etc. the question now is, what impact does guidance and counselors have on students? What are the challenges faced by these counselors and how can they be mitigated? This study was based on the principles of person-centered and social learning theory. The person centered theory emphasizes on the human interaction between two people (the counsellor and the client, in this case). Social learning theory, on the other hand, postulates that a child learns behaviour through social interaction in the form of observation and imitation of what other people in the society are doing. The researcher therefore recommends that there is need for all Cameroon University counsellors to be taken through a thorough and informative training on the importance of giving full support to guidance and counselling programmes in their institutions. There is also need to work to change the negative attitude towards guidance and counselling held by some students and parents.
\end{abstract}

Keywords: Effective Provision, Guidance and Counseling Services, Trends and Challenges.

\section{INTRODUCTION}

An organized guidance and counseling programme is essential in assisting students cope with the stresses they face while in and out of school. Some of these stresses according to Melgosa (2001) include physical and psychological changes they face due to adolescence. The challenges of adolescents according to Melgosa (1997) include adapting to their new image, facing the growing academic demands, establishing vocational goals, learning to control sexuality, emotional and psychological independence from their parents. Some of the learners in secondary schools are at an adolescence stage and an effective guidance and counseling programme in schools must be availed to assist these students (Melgosa, 2001). The rationale to offer guidance and counseling services to University students is clear. The University years is a periods of academic, social, personal, emotional and intellectual growth for most if not all students. By resolving physical, emotional, social and academic difficulties of the students and by helping students understand their learning strengths and weaknesses; their academic achievement can be improved and their overall development can be enhanced. Beside this, the increasing complexities in the society, industrial and technological development, changes of the nation's educational system and increasing number of students necessitates the provision of effective guidance and counseling service more than ever before. Thus, 
supporting all University students in all aspects of their development is very critical to their success. University systems must be ready, willing and able to deal with challenges that adolescents face in going through the transitions (Haregewoin \& Yusuf, 1994;Oladele, 1987). The guidance and counseling department in Cameroon Universities, is supposed to specifically provids expert direction which promotes the student self growth and wise decision making. This could be done through teaching, advising, instructing, explaining, and opinion giving that enables learners develop self esteem (Nguyia, 2010). They also develop their personal needs and evaluate the societal challenges facing them, abilities and gradually develop life's goals that are individually satisfying and socially acceptable (UNESCO, 2000), but this is not the case in Cameroon state Universities.

University counselors provide counseling programmes in three critical areas: academic, personal/social, and career. Their services and programs help students resolve emotional, social or behavioral problems and help them develop a clearer focus or sense of direction. Effective counseling programs are important to the University climate and a crucial element in improving student achievement. University counselors, like all educational professionals, are increasingly being required to demonstrate evidence of effective practice. This article provides concrete reflections to determine how Cameroon Universities are cribbing in meeting the needs of students through guidance and counseling programmes. Also a collection of sources that address the effectiveness of school counseling and other student support services, including their contribution to the personal and academic success of students is well addressed in this paper.

\section{BACKGROUND OF THE STUDY}

The role of school counselors has changed over time. At the turn of 20th century, school counselors did not exist, rather, teachers used a few minutes of their day to provide students with vocational guidance (Bower \& Hatch, 2002). In the early 1900s, an influx of various types of students in the public schools occurred as a result of the industrial revolution, initiating the development of the school guidance movement. At this time, the purpose of the guidance counselor was to avoid problem behaviors, relate vocational interests to curriculum subjects and develop character. Guidance and counseling services are essential elements in discipline management of people in all societies. Even the most primitive societies grew out of the necessity of guiding individual behavior patterns in the interest of the group. Society itself could not function without the exercise of discipline. Using guidance and counseling to promote discipline must continually be practiced if people are to work harmoniously for the achievement of the common purpose. The role of guidance and counseling in the administration and management of student discipline in Cameroon has been recognized by various government policy documents since independence.

Guidance and Counseling is a professional field which has a broad range of activities and services aimed at assisting individuals to understand themselves, others, school environment and attain abilities to adjust accordingly. Adjustment refers to a process in which an individual find and adopt modes of behaviour suitable to or the changes in the environment. Hence, University adjustment involves an individuals' general adaptation to own environment and the demands of life such as the way one relates to other people, that is interpersonal behaviour, handles responsibilities, deals with stress and meets own needs and life satisfaction. The need for guidance and counseling services in all Universities cannot be overstated due to increasingly complexities of modern life that have placed heavy demands and responsibilities on University students. These students are faced with numerous personal, academic, social and emotional needs and problems when unattended could lead to host patterns of undesirable behaviours (Weiten, 2007). School guidance and counseling programmes have therefore been introduced to assist students to overcome and adjust to a host of social and emotional challenges they experience at home and at school. Virtually, all countries have established channels to intensify and improve guidance and counseling services in their respective learning institutions in an attempt to address tenets of students' behaviours. The history of guidance and counseling around the world varies greatly based on how different countries and local communities have chosen to provide personal.

The history of school counseling formally began in the turn with the twentieth century, though a case might be made for tracing the foundations of counseling and advice rules to ancient Greece and Rome with all the philosophical teachings of Plato and Aristotle. There's also evidence to argue that some of the methods and abilities of modern-day guidance counselors were practiced by Catholic priests in the middle ages, as may be observed from the determination to the idea of confidentiality within the 
confessional. Close to the end of the sixteenth century, one of the 1st texts about profession solutions appeared: The Universal Plaza of All the Professions with the World, (1626) written by Tomaso Garzoni quoted in Guez, W. \& Allen, J. (2000). Nevertheless, formal guidance programs using specialized textbooks did not start until the flip of the twentieth century.

The most dominant single influence on the cause of one's life is the person's work. This also affects one's family structure, social and intellectual activities, economic position, personality and happiness. One"s occupational/career choice is mostly influenced by parents, friends, relatives, teachers, printed information, scholarship awards and pressure groups etc. Career decision making, is a process of finding the best possible match of a person with a particular kind of work. Dada (2005) asserts that many youths do not know what to do when they plan to take decisions on occupational choices; these eventually lead many to take on wrong jobs. Also, many graduates presently do uninteresting jobs, which they got into due to lack of career decision-making. Ike (1997) further opined that a lot of students do not know what to do with their lives and where they're going after school. Therefore, to assist such students develop their potentials, the school guidance and counselling programme must be effective to guide them regarding the requirement of specific occupations; the services of the guidance and counsellors are highly required as their efforts assist in placing talents where it is mostly needed.

Guidance and counselling on the other hand, is a helping career, which is a moulding, rebuilding and rehabilitating process. It is a self informative relationship, and it is both pre-emptive and restorative of maladaptive and self destructive tendencies. Guidance and counselling focuses on individual and its highly required in the schools, colleges, higher education institutions, hospitals, in courts, in the industries and companies; but for the purpose of this paper, the main focus is on guidance and counselling programmes in the secondary schools. Formal guidance and counselling can be traced to America in the late 1890s and the early 1900s. Frank Parsons who has been called the father of vocational guidance was among the pioneers of the guidance and counselling movement. Through his efforts, guidance and counselling became an organized service and it gained recognition for its important contribution in society. Parsons established the first career institution in the U.S.A, and set the pace for the development of psychological testing. Gradually the guidance and counselling movement developed into an organized service, which has continued to make a significant contribution to the development of society (Makinde, 1984; Nyamwange, Nyakan and Ondima, 2012).

Counseling is an idea that has existed for a long time in Tanzania. We have sought through the ages to understand ourselves, offer counsel and develop our potential, become aware of opportunities and, in general, help ourselves in ways associated with formal guidance apply. In most communities, there has been, and there still is, a deeply embedded conviction that, under proper conditions, people can help others with their problems. Some people help others find ways of dealing with, solving, or transcending problems as Nwoye, (2009) prescribed in his writings. In schools, presently if the collaboration between teachers and students is good, students learn in a practical way. Young people develop degrees of freedom in their lives as they become aware of choices and take advantage of them. At its best, helping should enable people to throw off chains and manage life situations effectively. Unprecedented economic and social changes have, over the years, changed the ways in which we manage our lives. Consequently, not all the lessons of the past can effectively deal using the challenges of modern day times. Effective counseling, especially in institutions of learning has now become important. Boys and girls, and young men and women, need to be guided in the relationships between health and the environment, earning abilities, knowledge, and attitudes that lead to success and failure in life. The need for counseling has become paramount in order to promote the well-being with the child. Effective advice and counseling should help to improve the self-image of young people and facilitate achievement in life tasks. Counseling should empower girls and boys to participate fully in, and benefit from, the economic and social development of the nation.

Bhatnagar and Gupta (1999) define guidance as a process of helping the individual find solutions to his/her own problems and accept them as his own. Ipaye (1983) stated that guidance is a general label, an umbrella term that covers all the means whereby an institution identifies and responds to the individual needs of pupils/students and thereby helping the individual to develop his or her maximum potential. Counseling, on the other hand, is a subset of the general term we call guidance services. The purposes of guidance and counseling $(\mathrm{G} \& \mathrm{C})$ programs for school children are many folds. Empirical evidences showed that $\mathrm{G} \& \mathrm{C}$ programs had significant influence on improving discipline problems 
(Baker \& Gerler, 2001), enhancing students grades (Gerler, Kinney \& Anderson, 1985), strengthening social skills (Verduyn, Lord \& Forrest, 1990), helping students make wise decision on career development and college choices and developing positive study habits and study skills.

\section{Statement of the Problem}

Guidance and counselling programmes in Cameroon education system has not been given the attention it deserves. And until the attention is given to this form of education programme, majority of University students will continue to find it difficult in career decision making. Okolie (2014) asserts that many college students lack ideas on which course to study in the higher education institution after leaving the schools. The reason is because; they lack services of professional guidance and counsellor who will assist them in career decision-making. It has been observed that many students who perform well in mathematics and science technology related subjects in secondary schools end up studying arts or social science related courses in the University instead of studying science, technology or engineering related courses to pursue their careers the relevant fields; this is mostly seen in Cameroon education institutions. After been admitted into the University, such students find it difficult copping with other students who choose the right courses leading to their chosen career path.

According to Haregewoin and Yusuf (1994), the people in the traditional helping professions (religious people, elders, or parents) do not have any scientific training. Hence, their help is insignificant to the present day adolescents. Oladele (1987) also argues that counselors must have a fairly high level of psychological sophistication in their profession in order to meet the different expectations of their clients. According to him the quality of counseling services rendered depends a great deal on the training of the counselors. Considering these facts, G\&C personnel are being trained in Cameroon tertiary institutions and sent to schools to deliver services. Although considerable resources are expended to train these professionals, no data have been collected to describe their programs and activities. There is a need, therefore, to assess the G\&C services rendered by University guidance and counselors.

\section{CONCEPTUAL ISSUES OF IMPLEMENTING GUIDANCE AND COUSELLING IN UNIVERSITIES}

\subsection{The Concept of Guidance and Counselling}

Guidance and counselling is described as an enlightened process whereby people help people by facilitating growth and positive adjustment through self-understanding. (Kolo 2001). Akinade (2012) defines guidance and counselling as a process of helping an individual become fully aware of him and the ways in which he is responding to the influences of his environment. It further assists him to establish some personal meaning for this behaviour and to develop and classify a set of goals and values for future behaviour. Corey (1988) regards counselling as a process which occurs in one to one relationship between an individual troubled by problems with which he cannot cope with and a professional worker whose training and experiences have qualified him to help others reach solution to personal needs. Okoye (1990) viewed counseling as an interactional relationship designed to facilitate the personal development of information leading to effective decision making and awareness of the self. Counselling is a learning process in which a counsellor helps an individual or individuals learn, understand themselves and their environment and be in a position to choose the right type of behaviours that will help them develop, grow, progress, ascend, mature and step up, educationally, vocationally and socio personally. ( Egbo, 2013).In other words, counselling is a transformative process of helping people to learn all that are to be learnt both in and outside the School.

Abolade (2000) describes teaching as a set of activities that are designed to bring about changes in the behaviour of learners. Bamgbaiye (2005) sees teaching as explaining, demonstrating, guiding and counselling by the teacher in order to effect a change in the learner. Okoye (2010) stated that the main aim of teaching is to help someone acquire or change some skills, attitude, knowledge, idea or appreciation. In other words, it is to bring about some desirable changes in the learners, she also noted that teaching is said to be effective only when the learners have been able to achieve the set behavioural objectives. Nnabuike, (2012) believes that a teacher is also a learner because there is no end to learning. Okoye (2010), views learning as the mental activity by which knowledge and skills, habits and attitudes, virtues and ideas are acquired, retained and utilized resulting in the progressive adoption and modification of conduct and behaviour. Idowu (1989) sees learning as the acquisition of new behaviour or a change in behaviour whether positive or negative change. It also includes acquisition of knowledge, information, skills and cultures. He therefore noted that learning definitely 
will lead to change in one's thought, patterns and feeling. Learning also involves cognitive process especially mental reasoning. Thus teaching and learning go together; it is like buying and selling. If nobody learns it follows that nobody teaches. Nnabuike (2012) noted that the work of the teacher is to help students to learn through deliberate and conscious manipulation of information, knowledge, skill, values, attitudes and habits of the learners in order to bring about learning, leading to desirable changes in character. Based on the above, no effective teaching could be said to have taken place if learning has not occurred.

\section{TyPes of COUNSEling}

There are two major types of Counselling, namely: individual counselling and group counselling.

\subsection{Individual Counseling}

This is referred to as one-to-one counseling. It occurs between the professionally trained Counselor (Therapist) and his client (Counselee). The goal of this is to help the client to understand himself, clarify and direct his thought, in order to make a worthwhile decision. Through this, clients' problems are alleviated. Frumboltz and Thoreson (1967) as cited in Ojo (2005) remarked that it is mainly to bring about change in the client either by altering maladaptive behavior, learning the decision making process or preventing problems.

\subsection{Group Counselling}

This is a counselling session that takes place between the professionally trained counsellor and a group of people. Number of this group should not be more than seven, or at least ten, in order to have a cohesive group and an effective well controlled counselling session. Members of the groups are clients/counselees whose tasks or problems that are meant for resolution are similar. During group counselling, a free atmosphere is allowed and freedom of speech is encouraged. The counselees are free to express themselves individually as counselling progresses so that problems to be resolved would be open for all to consider and benefit from. All counselees express their feelings and the counselor during group counselling is to help remove the marks covering the problem. He helps open up the problem with the professional competence and knowledge he possesses. The counselor is not just a member of the group; he is to direct the affairs and situations.

\section{The Counsellor And Counselling}

The counsellor in this context is a professionally trained teacher and therapist who should be working in the University. The role of the teacher counsellor revolved around employing new skills to aid the client/learner through the "dark entangled forest" (unknown) of his/her personality and society. Universities can help in terms of offering counselling or interpreting it in a broad way, by integrating it into the ethos of the school, and offer individual or group counselling. Lang (1993) agrees that for Universities, effectiveness in counselling depend on counselling being considered in its broad sense, and integrate it into a whole school approach. Whether integrated, group or individual, the counselling process should be handled sensitively and discreetly. Counselling aims at empowering the individual. The teacher-counsellor requires professional training to accomplish this task successfully. Castillo (1978) acknowledges that anyone who hopes a child to mature must first get to know and accept him for he is. Otherwise success will evade even his/her best affairs. Makewa (2008) concedes that it is important to understand the youth's world as a counsellor. The counsellor is then able to help them better when they understand them and that boys and girls are easier to build than it is to mend men and woman. A counsellor should have an interest and consuming desire to relieve distress and assist people lead more fulfilling lives. The counsellor must go beyond mere interest in the subject and equip him or herself with the relevant knowledge. Ndirangu (2000) concedes that the teachercounsellor should be well grounded in clinical psychology where it is dictated by the maxim that all behavior is caused. The teacher-counsellor requires knowledge of some culture values and beliefs of most of the clientele he or she handles within the learning institution. This is crucial because cultural misinterpretation may mean long-term damage to the client. It is not a wonder then that the MapRobinson Report (1987) comments that guidance and counselling for individuals has always formed part of the African strategy for combining personality problems and may be practiced by indigenous counsellors. The Witmer (1990) Report endorses this argument by remarking that counsellors should always be cognizant of the cultural conditions and changes. Teacher-counsellor should design comprehensive guidance programmes, provide counselling service and use assessment procedures 
with a gender perspective. Lack of training of counsellors in gender analysis may lead many providers of guidance to render services and/or organize activities that may continue to maintain and enforce the already existing stereotype. Counselling skills are learned over time and should be practiced by a professional teacher-counsellor as much as possible. Counselling is a purposeful process which leads client to move understandings of themselves and other; the teacher counsellor should therefore be conversant with the listening skill. Counselling is a process and theory based.

\section{Guidance and Counselling Programme and Discipline in Universities}

Human needs necessitate new inventions. Although guidance and counselling was focused on career development, contemporary socio-economic issues (unemployment, drug, unstable families, and truancy) have necessitated the incorporation of professional guidance and counselling in University. This is because guidance and counselling is safe to apply for holistic development of students, their behavior notwithstanding. Ayieko (1988) says guidance and counselling plays a pivotal role in students' behaviour management and correction in University. Counselling can be used both as a curative measuring in addressing school discipline and to avert and/ or correct indiscipline among students. Guidance and counselling may be provided holistically in University. Vocational Guidance provides information about job opportunities and factors affecting the job market such as unemployment information technology and international relations. Mutie and Ndambuki (1999) look at the aims of vocational guidance as having an expanding function, to aid in placing talent where it is needed. Through education guidance, a learner is better informed about the subject they study and subject choices; and that to attain success in one's academic requires learners going an extra mile in their studies. The kind of Knowledge to learner is especially important to the youth who are less exposes and limited in their understanding of the world of work.

Parents, teachers and society are observing and reporting a marked decline in the level of indiscipline and good behaviour among University students in Cameroon. Most of these students generally lack courtesy, respect, self-control, decency, and social etiquette. The values they portray are disrespect toward authority, promiscuity drug abuse, addiction behaviour and carefree lifestyles. A learner in a new school or in a higher level of learning institution is to cope with the new environment through guidance. Learners are helped to develop a better understanding of whom they are and appreciate of their background. Learners are guided on the self-awareness, peer pressure, relationships, personality differences, manners and social etiquette, social roles and responsibility, intra and interpersonal conflict resolutions. Though personal and social guidance, a pupil is helped to overcome indiscipline as a quest for 'freedom. Indiscipline among University students is a result of a feeling of unfulfilment, frustration and lack of constructive freedom.

\section{An Effective Guidance and Counselling Programme within an Educational SETTING}

According to Zeran and Antony (1962) a good and effective guidance and counselling programme is essential in every school. An organized guidance and counselling programme will offer right environment for the growth and development of the student and offer quality education. Gichinga (1995) acknowledges that there has been steady growth of guidance and counselling programme within educational settings. The major emphasis has been on vocational and educational guidance and counselling aimed at fostering personal/social development. An effective guidance and counselling programme should be led by a trained counsellor who is responsible for coordinating guidance and counselling activities in the school (Nelson, 1972). Makinde (1984) observes that the trained counsellor is a leader and consultant in the school "es student appraisal programme and also helps to plan and develop guidance and counselling programme and the curriculum in relation to students ${ }^{\text {ee }}$ needs. Kyungu (1994) argue that effective 12 guidance and counselling programme should have active cooperation of teachers, teacher counsellors and administrators. The school should make arrangements to enlist the support of the parents and introduce them to the idea of guidance and counselling. Therefore, in an effective guidance and counselling programme, various guidance and counselling services are offered to assist students in personal development and psychological growth towards maturity. According to Schertzer and Stone (1976), these services include the following:

\section{ORIENTATION SERVICES}

Orientation services are provided to help students to adjust better to school environment. According to Makinde (1984), when new students are admitted every new academic year in secondary schools, they 
feel lost socially and psychologically in their new environment. This is because they no longer enjoy the psychological support of their parents, friends and former teachers. Also the new environment has rules, regulations and administrative set-up appears completely different. Orientation services are therefore designed to help such students adjust during such critical transition periods. Good guidance programme is hence drawn to familiarize then with the overall school situation.

\section{Appraisal Services}

Appraisal services involve a teacher counsellor collecting, analyzing and using a variety of objective data that can enhance better understanding of the student. A teacher counsellor without adequate and reliable information of a student will have difficulties in assisting him/her (Makinde 1984). It is therefore important to collect and make available a variety of information through observation, interview, testing, history, and social adjustment data about each student so that they can be in a position to plan satisfying educational, vocational and social programme.

\section{EDUCATIONAL AND OCCUPATIONAL INFORMATIONAL SERVICES}

These services have the aim of providing students with better knowledge of educational, vocational and social opportunities that can be used to make better and well informed decisions. In Universities and secondary schools, students need at all times to make decisions about their education, career and social life Borrow (1983) Mutie and Kochhar (1992) observe that students need information related to job opportunities, training opportunities, and academic qualifications required.

\section{Counselling Services}

Counselling services are designed to help an individual student analyze himself/herself by relating their capabilities, achievements, interests and mode of adjustment to what new decision they have to make Gichinga (1995) These services are very critical for the students because they need it to solve career, study, personal and social problems they encounter in life. The school is supposed to provide time, place, and personnel required for skilled assistance of individual students in working out solutions to their personal problems. The services are designed to facilitate self-understanding through individual or group relationships. Kyungu(1994)support this by observing that effective guidance and counselling in secondary schools and other learning institutions has become extremely important in guiding students on the relationship between health and the environment, life-earning skills, the knowledge and attitudes that lead to success or failure in life. Effective counselling service should assist in improving the self-image of the students and facilitate better achievement in academic performance.

\section{Placement and Follow-Up Services}

The placement services are very essential at the end of secondary school education, where students need to decide on the next step after secondary school. These services assist students in selecting subject combinations required for particular courses and choosing of the right careers. Makinde (1984) states that placement service is designed to aid an individual to select and utilize opportunities within the school and in the labour market. Follow-up services are needed follow or trace a student after school and to the world of work. School counsellors develop a systematic plan for maintaining contacts with former students. Makinde (1984) notes that the data obtained from follow-up is kept in the school and it is used in evaluating the effectiveness of the entire guidance and counselling programme. A conducive environment for the student should be provided and teachers should provide room for self-actualization by being friendly, loving, competent and responsible. Teacher counsellor should also help the student set goals and allow positive self recognition after attaining set goals and aspirations that will boost success in academic performance. Therefore, a good environment should be created by teacher counsellor.

\section{The Role of The Teacher Counsellor}

Initially, when the guidance and counselling programme was introduced in secondary schools, the role of the appointed counsellor was limited to giving information on career/vocational choices. With time however, it was noted that students had other problems other than just educational. In the 1980s and 1990 s, a counselling element was added to the original guidance programme. The Koech Report (1999) recommended that a counselling element be added to guidance in order to help students overcome their personal problems. 
Rogers (1961) also said that guidance and counselling should help a client to attain a selfunderstanding which will facilitate change of behaviour, change of attitude and identification of special talents and abilities. In the light of this therefore, the role of a guidance and counselling provider in an institution is to: help people experiencing difficulty to overcome or cope with it and to understand the environment very well so that she/he can anticipate, circumvent and, if possible, forestall difficulties which may arise in future, therefore preventing students from falling into them. It is also her/his role to help the individuals to plan and derive maximum benefits from educational, social and vocational experiences which will enable them to discover and develop their potential (Makinde, 1984). In order to do this, the counsellor should be a trusted confidant to all learners by showing a positive attitude and disseminating to and receiving appropriate information from counsellees. The information should also be used to help each student to strengthen his own abilities (Durojaiye, 1980). The counselor should also work in cooperation with other teachers to identify each student's unique and special mental abilities, aptitudes and creativity then assist her/him to develop a realistic self-image. Sindabi (1992) also underscores this by saying that a counsellor should be one who is knowledgeable on the nature and pattern of problems that students are likely to deal with and the adjustment mechanisms that they use when they are unbalanced or uncomfortable.

\section{FACILITIES FOR COUNSELling}

Much as the Cameroon government has recognized the importance of guidance and counselling in our educational institutions, it has not, however, provided the resources necessary for creating a conducive environment for offering the services. Makinde (1984) recommends that schools should provide finances which will allow the school counselors to have equipment, materials and travel allowances necessary for them to carry out their functions. The funds thus provided would enable the counselor to get a regular supply of books, journals, magazines and visual aid materials, which in turn, will equip her/him with current and accurate information for students. A counsellor will also require to occasionally inviting a specialist speaker to talk to students or to take them out for tours based on relevant issues.

Unfortunately, many educational institutions do not set aside such funds. Sindabi (1992), notes that counsellors have inadequate facilities and this makes it difficult for an effective implementation of a counselling programme. Engelkes and Vandergoot (1982) observe that there should be private and confidential areas for counselling. Chairs should be comfortable, preferably with arms and the room should have enough lighting. Mutie and Ndambuki (1999), also say that an ideal guidance and counselling center should be a large room with display racks, bulletin boards and tables where materials can be maintained and displayed. The room can be used for holding discussions, showing films or holding parent-teacher meetings. Group counselling can also be done there and part of it can be partitioned for individual counselling. Unfortunately, most Universities in Cameroon do not have even an office for the teacher counsellor. Besides that, guidance and counselling is not timetabled and lacks enough staff to deliver the services.

\section{STUdents' AtTitude towards Guidance AND Counselling}

Masinde (2003) says that students in Universities and colleges experience a variety of emotional, social, academic and psychological problems for which they need support in order to enable them to go through University life. Dameroon and Borland (1980) say that guidance and counselling in University can help learners to grow in self-understanding, develop their capabilities for making career decisions, progress and achieve an all round growth besides just problem solving.

According to Bischoff (2005) the individual is mostly responsible for what he becomes, meaning that it solely lies in his responsibility to take such action towards change in case of perceived problems which he wants to have solved. It is the client who must facilitate his own change. It follows therefore, that the counselor and the client must build a relationship in which the counsellor succeeds to empower the client to take action towards change in the solution finding process. In most African traditional settings, however, problems are solved involving the help of the members of a given system, the individual, particularly a child, has no decision making power on his own whatsoever. The student in the Cameroon system is used to decisions being made at the top and being told what to do. Such people go to a counselor expecting to be given advice on what to do with a problem besetting them. Counsellors on the other hand, fall into that trap of advice giving because the counsellor is herself/himself part of the culture. 
This tendency is a great hindrance to effective counseling programmes as it will not as lead to behaviour change as the decisions have not come from the client. Piaget (1965) noted that adolescents, impressed with their own theories, often fall victim to a new form of egocentrism. They cling rigidly to their views, refuse to believe that they might be incorrect, and assume that no other views can match theirs. In fact they tend to think that counselling is for those who have obvious mental, learning and behavioral problems. According to such students, a counsellor should be seen only when they need academic assistance. This age bracket never wants to admit openly that they have any problem as this might be interpreted to mean weakness (Masinde 2003). Migiro (1996) found that some students are skeptical about seeking guidance and counselling services because they do not want to reveal their problems to their teacher counselor. According to them such revealed problems are later made subjects of staff-room debate. Nyabwari (2003) also reports that a number of students hold a strong misconception towards guidance and counselling that hinders them from freely telling their problems to the teacher counsellor. They think that they will be punished if they reveal their problems.

According to Masinde (2003) one other challenge facing effective implementation of counselling in University is a rebellious attitude from students about their admission into the institutions. Many youths neither apply to neither join nor choose the courses they study; they are taken there by parents/guardians who choose courses they feel are "good"e for the youth without consulting her/him. On getting to the University the youth realizes that there are better suiting courses she/he could have taken and she/he even has the required marks. She/he gets demoralized, stops working hard and does not care about whatever happens to her/him. Such a student just drifts away and will not seek help.

\section{Gender Of Student AND Counsellor}

Lot et. al. (1999) observed that gender issues play a role in hindering delivery of the services. Their study found out that counsellors in schools handle more female than male clients. Possible explanations towards this have been offered: gender socialization processes where, from an early age, women are encouraged to seek help when they have problems while men are discouraged from it. Sanders (1996) say that another possible reason to this disparity has to do with referral services. A woman is likely to refer another woman to a counsellor, but a man will not refer another man to a counsellor.

Khan and Nauta (1997) confirm that male students are more negative towards seeking for counselling than female ones. Most men think it is an indication of personal weakness if one seeks for psychological counselling. This does not mean however that male students experience fewer problems than females. Masinde (2003) notes that a number of students in colleges suffer stress and anxiety due to: failure in examinations, uncertainty about school fees, and pressure from guardians to excel, inability to cope with school work and personal relationships. As a result, most male students get openly drunk, walk aimlessly in the college compound arguing loudly to themselves or they just sit at the students ${ }^{\text {ee }}$ center without attending classes. The researcher also observed that it is possible that male students may never seek help from a counsellor who is female because the African culture never allows a man to go to a woman for guidance. Deaux and Wrigtsman (1984) confirm this gender bias by saying that when given only general occupation about individuals at work situations, people assume that the woman has a lower status job and that the man has a higher status job. People also believe that the man will be more influential than the woman.

\section{Teacher CounSEllor's Training}

Gibson and Mitchell (2008) consider guidance and counselling a helping profession similar to Medicine, Law, Dentistry, Education and Social Work. They say that a helping profession is one in which the members are specifically trained and licensed or certified to perform a unique and needed service to fellow human beings. According to them, professional counsellors must be fully trained and qualified to meet the needs of the client population they are designated to serve. They recommend that school divisions should ensure that persons fulfilling the role of counsellor are adequately trained and should have completed a programme in counselling, including supervised practice in guidance and counselling. Once trained, the teacher counsellors should then employ their knowledge, skills and understanding to draw up a procedure that is ample enough to include and cater for the various needs of individual pupils within the school framework. ROK (1976) noted that lack of trained counsellors in some Kenyan schools has impacted negatively on the delivery of these important services. For a 
long time, guidance and counselling in schools was done on a voluntary basis by untrained teachers, hence ineffective services. It was then recommended that all teacher trainees should take a compulsory course in guidance and counselling and practicing teachers be provided with in-service courses.

ROK (1978) observed that lack of training of teacher counsellors may have contributed to little success in the provision of guidance and counselling services in schools. Training equips the counsellor with appropriate skills and psychological knowledge necessary to be able to assist the client. This knowledge helps the counsellor to appropriately understand the clients ${ }^{\text {ee }}$ problems and use the proper psychological school of thought to offer assistance (Durojaiye, 1980). An untrained counselor will have difficulty in explaining types of behaviour, how they are caused and how they can be modified (Huffman, 2002). Engelkes (1982) also notes that the limits of what one can do are fixed by available expertise, methodology and equipment. The Nation Blackboard (2002) pointed out that the major factor contributing to the failure of guidance and counselling programmes in schools is the lack of trained personnel to handle the subject. When the behaviour of a student is as a result of underlying factors, particularly those spanning from childhood, most teachers tend to deal with manifestations rather than the causes. This is mainly because of lack of proper skills to unearth the actual challenges of the students, when the teacher counsellors are not trained (Mwagiru, 2002).

\section{Challenges and Problems Facing the Promotion of Guidance and COUNSELling SERVICES IN UNIVERSITIES AND SECONDARY SCHOOLS}

Odu (2004) stated that the main aim of guidance and counselling is to assist the student to develop physically, mentally, emotionally, morally and educationally to cope with the learning situations within and outside the school environment. Some of these services provided by counsellors are hindered because of the following problems;

1) Lack of trained counsellors: Despite the fact that there are many holders of higher degrees in guidance and counselling in Cameroon today, not as many are qualified to be real counsellors because they lack the skills necessary for the practice. There is limited number of trained counsellors in Caneroonian schools and the ones already trained choose to go into non-school settings.

2) Doubt about the efficacy of guidance and counselling: Some people such as uninitiated colleagues, teachers, principals or administrators doubt the efficacy of counselling. They are skeptical about reliance on its use. (Orubu 1986, Akinade 1990).

3) Lack of commitment of Government officers: although the Government entrenched the guidance and counselling programme in the Cameroon University education systen, there is still much to do when it comes to practical support and its implementation. He noted that more committed action will help the growth of the profession.

4) Lack of or inadequate funding: Guidance and counselling is not well funded today, the education enterprise has become a costly venture. Enough funds are not allocated to each University to run its various services. Where funds are available, very little is earmarked for counselling purposes. It seems the government do not want to stretch their budgets with extra demands from emerging unit such as guidance and counselling, yet it is known that effective counselling demands adequate funding to purchase items such as psychological tests, journals and various publications, play gadgets, cardboards and various felt pens as well as money to organize activities such as Orientation, Excursions, career clubs and Career Day/week and furnishing a counsellor's office.

5) Confidentiality: Clients expect that their secrets or privileged information be kept secret or confidential and not exposed to others. However, referrals agents such as teachers, peers, parents, principals etc expect counsellors to divulge such information to them. Failure of the counsellor to reveal the "secret" may raise the degree of suspicion of his activities. Revealing the secrets lead to loss of faith in counselling and counsellors on one part will lose clients. Yet all these are happening.

6) Counsellors created problems: Counsellors also create major problems to guidance and counselling delivery. Some are not fully committed to the counselling profession. Instead of being serious minded in their counselling duties, some join in the staff room discussions. 
7) Feeling of suspicion of the role/of integrity of counsellors: Some school personnels still see the counsellor as having a "hidden agenda" or something to hide when a client goes into the counselling room (where this is available) some give counsellors negative or derogatory labels. This is more so where the other workers doubt the moral integrity of counsellors who give individual counselling to young ones. This feeling becomes more serious when a male counsellor treats female students and gives the interaction high confidentiality.

8) Blurred role of the guidance counsellor: Several people in the society do not know the specific roles of the counsellor. Even in the school settings, where awareness is expected to be high, school personnel such as teachers and principals do not understand or they misconstrue the functions of the counsellors. For instance, Makinde (1980) wrote that head teachers see them as rivals instead of helpers.

\section{THEORETICAL FRAMEWORK}

This study was based on the principles of person-centered and social learning theory. The person centered theory emphasizes on the human interaction between two people (the counsellor and the client, in this case). Social learning theory, on the other hand, postulates that a child learns behaviour through social interaction in the form of observation and imitation of what other people in the society are doing.

\subsection{Person-Centered Theory}

This theory focuses on the human interaction between the counsellor and the client. Rogers (1980) called it the Person-centered theory in order to suggest that his principles extended beyond the clienttherapist relationship to encompass all human interaction. The current personcentered theory is understood as a process of helping clients discover new and more satisfying personal meanings about themselves and the world they inhabit. The student will drive towards growth, health and adjustment (Makinde, 1984). The model assumes that human interaction is only possible when certain conditions prevail. In the case of guidance and counselling, these conditions should prevail sellor"s demonstration in the counsellor-client orientation.

According to Omulema (2000), these conditions include counselor"s demonstration of empathy, unconditional positive regard and warmth to the client. He notes that growth occurs in an acceptance, warm, empathetic, non-judgmental environment that allows students the freedom to explore their thoughts and feelings and to solve their own problems. Guidance and counselling programme that lacks these characteristics culminate into poor performance of students in school. When a counsellor communicates the above conditions, those being helped will become less defensive and more open to themselves and their world and they will behave in more social and constructive ways. Many students habour feelings of failure in academics and thus have low self esteem, but a counsellor is able to counter the feelings by working towards fostering the students capacity to hope and believe that they are capable of overcoming academic failure they are experiencing and even end up performing their best potentialities.

\subsection{Social Learning Theory}

Learning is a process where behaviours are learnt or acquired from the environment. One way of learning is through social observation and imitation. This theory is advanced by Albert Bandura (1986). This theory explains delinquency as a behaviour learnt through the complex process of socialization. The theory postulates that the behaviour is reflective of people observing and imitating others and imagining the consequence of their own behaviour. The theory advocates that human behaviour is modified using learning principles to change behaviour (Omulema, 2000). The behavioural approach emphasizes that the client define goals in behavioural terms provide resources and encouragement in helping clients more towards goals and helps clients with different problems (Patterson, 1973). Teacher counsellors can therefore apply this in counselling students concerning their academic performance. Makinde (1984) notes that counselling effectiveness and outcome of counselling are assessed by change in the specific studentes behaviour. This implies that counselling can use behavioural counselling to create a conducive environment for the students to modify their behaviours in order to solve their academic problems through creation of learning conditions. Teacher counsellors can use behavioural techniques like self management programmes and self directed behaviours which may deal with learning, study and time management skills in schools. This will 
foster the students ${ }^{\text {ee }}$ academic performance. The student will drive towards growth, health and adjustment (Makinde, 1984). Therefore, a good environment created by the teacher counsellor. School can provide room for good self-concept that will boost success in academic performance.

\section{EMPIRICAL REVIEW}

The review of empirical literature was very imperative for this study, it reveals through previous studies, what has been done, what needs to be done and how it should be done to improve on the provision of guidance and counseling services in Universities and secondary schools. It also, reveals the existing gap between present issues and trends in the provision of guidance and counseling services and previous perceptions and methodologies used for the same services. Therefore, empirical review of literature gave the researcher an opportunity to assess past and present University counselor's engagement in the provision of effective and reflective guidance and counseling services for the educational benefit of all students in Cameroon and beyond.

Boutwell and Myrick (2006) contend that guidance and counselling plays a major role of promoting students' success through a focus on social and emotional adjustment by means of prevention and intervention services, advocacy and treatment of emotional turbulence. In addition, guidance and counselling services provide students with the opportunity to learn more about themselves and others before they have problems resulting from fear, anger and grieving. Weissberg and Myrisk (2007) articulate that most students express a basic need of social and emotional adjustment which is grounded on foundations of comprehensive guidance and counselling services. These services integrate competence promotion and foster students' social and emotional development framework for reduction of risk and detrimental behaviours such as substance use, promiscuous sex, violence, depression and attempted suicide that deter success in life.

Also, Macharia (2007) contends that guidance and Counseling service seems to gain tremendous support in rural parents, counsellor and significant other aiming at sustainable social and emotional adjustment in comparison with rural settings where parents especially the dual career hardly spend ample time with their children. Moreover, Theodore (2002) holds the view that Guidance and Counseling seems to stimulate more self driven energy and capacity for living to societal norms and upholding ethical standard among rural females. This contrasts an urban set up where people live in a fragmented and alienated society in which there are minimal social and emotional support systems.

According to Mutie and Ndambuki (1999) schools counsellors play a vital and immense role in holistic growth and development of students. Weissberg and Myrisk (2007) confirm that students typically do not learn or exist alone, but rather in close collaboration with their school counsellors, peer counsellors and with encouragement from significant others. Corroborative and systematic guidance and counselling services are mandatory for excellence for excellence in academic, personal competencies social and emotional adjustment. According to Brigman and Campbell (2007), school counsellors help students acquire effective mastery of social and emotion competency for easy adjustment which is associated with greater-well-being, better academic achievement and desired behaviour. Horgan (2003) describes the role of guidance counsellors as equipping students with competence in area of social and emotional adjustment who obtain abilities to generate and coordinate flexible, adaptive response to daily needs, demands and pressures in a more profitable and constructive manner. UNESCO (2006) states that a hallmark of students behaviour modification rests on the Guidance and Counselling services. Brigman and Campbel (2007) crowns Guidance and Counselling as the leading school agency that develops, strengthens and maintains fundamental principles adjustment among schools students.

Sindabi (1992) views systematic desensitization counseling technique as the most appropriate tool that helps students cope and adjust to fearful emotion. Further, Sindabi (1992) points out some strategies used by counsellors to help students' manager fear and adjust their behaviour reactions. These techniques are geared towards change of behaviour. They include admitting fear, building selfesteem, building new differences learning principles and techniques of relaxation and consultation in times of need or crisis (Loescher, 2007). Wanjama,Njenga, and Henok, (2006) have identified school counsellors as key to influencing students' management of two fundamental emotional reactions which mostly determine the behaviour. Individual students are capacitated and empowered to vent out their feelings in ways appropriate and acceptable to their school norms (Hurlock, 2007). 
Kottler (2004) postulates that young people in school persistently experience difficult emotions due losses they seem to face. Conger and Peterson (1984) outlines losses of young people as demise of relatives, loss of personal property and even body changes. The counsellor's work with students to help them go through grieving constructively. Macharia (2007) observes that guidance counsellors step up students' ability to accept the losses, untangling oneself from the ties with lost item, and reinvesting one's energy into forming new relationships, setting new goals and cultivating fresh dreams and aspirations.

According to Karega (2008), learning in Universities is often interrupted by the deviant behavioural patterns of the adolescents. Dryafol (2002) pointed out that University students carry along with them a host of adolescent challenges. They are highly influenced by technological change and transformation. Also, the high school students experience erratic physiological changes resulting to unpredictable mood swings, social development and changes that are evident; for instance they become defiant to the authority (Conger \& Peterson, 1984). Sindabi (1992) postulates, that young people in Universities and secondary schools undergo emotional development, manifesting characteristics of being erratic, irritable, unpredictable, ambivalent, critical and rebellious. Collin (2007) depicts guidance and counselling as an ultimate icon that addresses students' social and emotional adjustment. Karega (2008) argues that lack of adequate social and emotional capacity of adjustment among University and secondary school students have resulted to unrests, riots and violent disturbances in Kenyan schools in the last two decades

\section{Conclusion}

Guidance and counselling is of paramount importance in effective teaching and learning in schools in Cameroon and globally. It is a transformer, reformer in educational, vocational and socio personal practices in every society. UNESCO 2002 has recognized the pivotal role which guidance and counselling plays in various spheres of human existence, hence it sponsored the development of training modules for counsellors. Counselling is aimed at helping an individual become aware of himself and his environment and therefore be in a position to choose the right type of behaviour, educational, vocational and socio personal in nature. Therefore guidance and counselling no doubt has a lot of roles to play for effective teaching and learning and therefore deserves maximum support of everybody.

\section{RECOMMENDATIONS}

The following recommendations are made for promoting effective provision of guidance and counseling services in Cameroon Universities and secondary schools:

1) There is need for serious enlightenment on the part of the public to accept guidance and counselling. This will help develop strategies for administrators and teachers to achieve a realistic perception of students in their school environment.

2) Government should support guidance and counselling practically by providing and making funds available for all the services in guidance and counselling.

3) Guidance and counselling should be made an integral part of University and secondary school programmes and therefore supported by all concerned.

4) The guidance counsellor should be consulted by all University administration in implementing some of the counselling programmes.

5) Guidance counsellors should be committed to the counselling programmes through helping the teachers with the identification of students with learning problems and inform the teachers, so that different individualized methods can be used for effective teaching and learning.

6) Government should help to train and appoint qualified guidance counsellors in Cameroonian state Universities and secondary schools to help meet with the student's problems.

7) Parents also should be included in guidance and counselling programme through giving them progressive report of their students.

8) Counsellors should understand their limits in helping the students and therefore make use of referrals. 
9) Counsellors should keep students secrets with utmost confidentiality.

10) There is need for the clarity about the services rendered by school counsellors. This is done by defining the counsellors roles, functions and objectives for the benefit of school administrators, teachers, students, parents, staff and community.

11) There is need for education stakeholders to initiate an in-service course programme for untrained teacher counsellors so as to empower them to be able to become meaningful helpers to students.

12) When posting the guidance and counselling personnel in the institutions, care should be taken to provide for both male and female counsellors so that the unique needs and preferences of each student gender can be accommodated.

\section{REFERENCES}

Ayieko, J.S. (1988). Solving discipline problems in Kenyan secondary schools. Nottingham: The university of Nottingham.

Bailey K.D. (1994). Sociology and the New Systems Theory: Towards a Theoretical Synthesis. New York: State of New York Press.

Baker, S. B. (1994). Mandatory teaching experience for school counselors: An impediment to uniform certification standards for school counselors. Counselor Education and Supervision, 33, 314-326.

Baker, S. B., \& Gerler, E. R. (2001). Counseling in schools. In D. C. Locke, J. E. Myers, and E. L. Herr (Eds.), The Handbook of Counseling, Thousand Oaks, CA: Sage Publications.

Bhatnagar, A. \& Gupta, N. (1999). Guidance and Counseling. Vol. II, New Delhi: National Council of Education.

Boutwell, L. D. and Myrisk. S. M. (2006). Comprehensive School Counselling Programs: A Review for Policy Makers and Practitioners. Journal of Counselling and Development (70) pp 487 498.

Brigman, G \& Campbell, C. (2003). Helping Students Improve Academic Achievement and School Success. Behaviour. Texas:Macmillan

Castilo, G.(1978).Teenagers And Their Problems. Nairobi: Focus Publishers Ltd

Conger, J. J. \& Peterson, A. C. (1984). Adolescence and Youth Psychological Development in changing World (3rd Ed) New York: Herper and Row Publishers.

Dameron J.D. and Borland D, (1980). College Student Personnel Development: Administration and Counselling. (2nd ed). Washington: Washington DC University Press of America.

Deaux K. and Wrightsman L.S (1984). Social Psychology in the Brooks. Mouterey Califonia: Cole Publishing Company.

Durojaiye M.O.A (1980). Psychological Guidance for the School Child. London.

Engelkes J. R and Vandergoot D. (1982). Introduction to Counselling. Boston, Houghton: Mifflin Co.

Gibson R. L, and Mitchell M. (2008). Introduction to Counselling and Guidance. New Jersy: Pearson Education Inc.

Gichinga, E .M (1995) Basic Counseling Skills Gem counseling Services, Kenya.

Huffman K. (2002). Psychology in Action (6th ed). New York: John Wiley and Sons.

Hurlock, R. L. (2002). Introduction to Guidance and Counselling in Schools and colleges. New Jersey: Education Upper Saddle Publishers.

Ipaye, T. (1983). Guidance and counseling practices. Ile-Ifc University Press.

Karega, M. (2008,July 14 pg 15). School Conduct and indiscipline Issues. Daily Nation. Nairobi: Nation Media Ltd.

Khan J. H. and Nauta M.M, (1997). The Influence of Student Problem-Solving Appraisal and Nature of Problem on Llikelihood of Seeking Counselling Service. Journal of College Student Development.

Kottler, J. A. (2004). Academic Therapy for Quality Education: Behavioural Science Research. Chicago: Behavioural Research Associations.

Kyungu, S.P (1994) Guidance, Counselling in Schools: A research Paper Presented to the Education Depertment. Stirling University (U.K) 
A Review of Effective Provision of Guidance and Counseling Services in Cameroon State Universities; Trends and Challenges

Loescher, N. W. (2007). Introduction to Guidance and Counselling in Education: Crisis Counselling in Schools and Colleges. London: Oxford University Press.

Macharia, M. (2007). Access to Success in School and Beyond. Nairobi: Sage Educational Media.

Makewa, P. W. (2008). Developing Youth. Nairobi: Uzima Publishing House.

Makinde O. (1987). Fundamentals of Guidance and Counselling. London: McMillan.

Makinde, O. (1984). Fundamentals of guidance and counselling. London: Macmillan Education Limited.

Masinde M. (2003). Problems Facing Students at Kenya Polytechnic. Unpublished Personal Research. Kenya Polytechnic, Nairobi, Kenya

Melgosa, J. (1997). To Adolescents and Parents. Madrid, Spain: Editorial Safelize

Melgosa, J. (2001). Less Stress (7 edition). Madrid, Spain: Editorial Safelize

Migiro N.N (2005). An Investigation into the State of Guidance and Counselling in Secondary Schools. Unpublished PGDE Project, Kenyatta University, Nairobi, Kenya.

Mutie E.K and Ndambuki P. (1999). Guidance and Counselling for Schools and Colleges. Nairobi: OUP.

Mutie, E. K. and Ndambuki, P. (1999), Guidance and counselling for schools and colleges. Nairobi: Oxford University press (E. Africa).

Ndirangu, J.M (2000) Youth in Danger: A Handbook for teachers, Students, Parents, Pastors and Community Workers. Nairobi: Uzima.

Nelson, J. R. (1972). Guidance and counselling in the elementary school. USA: Holt Reinehort and Winston Inc.

Nguyia, G. (2010).The Role of Guidance and Counseling in Schools in Makueni District. Unpublished M.Ed Thesis. University of Nairobi.

Ojo, O.D. (2005). A Guide to guidance and counselling practicum. Concept Publications. Lagos: Shamble

Oladele, J. O. (1987). Guidance and counseling a functional approach. focus on the 6-3-3-4 educational system. ( $3^{\text {rd }}$ ed). Lagos: Johns-Lad Publishers Ltd.

Oladele, J.O. (1985). Guidance and councelling; A functional approach Lagos; John-lad enterprises

Olayinka, M. S. \& Omoegun, M. O. (2001). Principles and practice of guidance and counselling. Ikorodu, Nigeria: Bab Sheriff Ltd. publishing.

Patterson, G. (1962). Vocational guidance and career development. New York: Macmillan Press. Psychological Forms. Robert, E., \& Elizabeth, (1983).

Rogers C, (1961). Freedom to Learn for the 80's. Columbus: Merrill.

ROK, (2001). Report of the Task Force on Students' Discipline and Unrest in Secondary Schools. Nairobi: Jomo Kenyatta Foundation.

Saunders S, (1996). Applicants Experience of Social Support in the Processes of Seeking Psychotherapy. In psychotherapy 33. Sous Inc.

Shertzer, B. \& Shelly, C. S. (1976). Fundamentals of guidance. Boston: Houghton Mifflin Company

Shertzer, B. \& Stone, S. C. (1980). Fundamentals of counseling. (3rd ed). Boston: Houghton Mifflin Company .

Shetzer, A. \& Stone, P. (1966). Fundamentals of guidance. New York: Houghstone Mifflin.

Sindabi A.M, (1992). An Analysis of the Guidance and Counselling Programme in Selected Secondary Schools Virginia. Unpublished Doctoral Thesis, Virginia Polytechnic Institute and State University.

Sindabi, A. M. (1992). An Analysis of Guidance and Counselling Programme in Selected Kenya Schools: Unpublished Dissertation. Falls Church Virginia.

Theodore, S. N. (2002). The Students' Guide to Exam Success: Focus on Excellence. London: Oxford University Press.

UNESCO, (2006).EFA Global Monitoring Report 2006.Literacy for Life. Paris. 
Verduyn, C.M., Lord, W., \& Forrest, G.C. (1990). Social skills training in schools: An evaluation study. Journal of Adolescence, 13, 3-16.

Wanjama, S. N. et, al. (2006). Guidance and Counselling in Education Setting. Nairobi: Uzima Press.

Weinten, W. (2007). Psychology: Themes and Variations. California: Wadsworth.

Weissberg, T. M. \& Myrisks, C. H. (2007). Resolving Conflict Creativity in Community Psychology and the Schools: A Prosocial Behaviour and Academic Achievement. Chicago: Behavioural Research Associations.

Witmer, J.M.(1990). Consultancy on Establishing a Guidance and Counselling Education at the University of Botswana. Ohio: Ohio University College of Education, Athens, Ohio-August 28th, 1990).

Zeran,F.R \& Antony (1962) Organization and Administration of Guidance Services; Chicago. Rand Mac Nally and Co.

\section{AUTHOR's BIOGRAPHY}

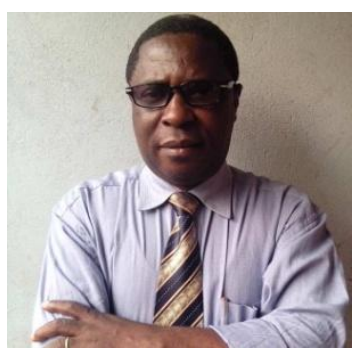

Dr. Tita-Nghamun Johnson Bobga, is a Senior Lecturer in Government Teacher Training College Limbe Cameroon. Dr. Tita-Nghamun has a PhD in Psychology of Education, a Master Degree in Psychology of Education, a Post Graduate Diploma (DIPENII) in Sciences Applied to Education and Bachelor Degree in Educational Foundations and Administration. As a career teacher, he is experienced and has taught at all levels of Education. Formerly he was the chief officer for Examination at the Inspectorate of Basic Education in Muyuka, G.C.E Examiner and Divisional Pedagogic Adviser for Ndian Division. Dr Tita-Nghamun Johnson Bobga is a visiting University Lecturer. He has several certificates of participation in Pedagogic Seminars/workshops. Dr. Tita-Nghamun Johnson Bobga is not only an academician he is a minister of God. He holds a Certificate and a Diploma in Ministerial Training from Cameroon Bible Training Centre and also a Certificate in specialized studies in Advanced Christian Leadership from Haggai Institute, U.S.A. Dr. Tita-Nghamun is a renowned Researcher working with: Foundation of Scientific Research, Community Based Rehabilitation and Advocacy on Inclusive Education" (FORCAIE-Cameroon). 